\title{
The Effect of Price Perception, Service Convenience, Service Quality and Brand Equity On Ticket Purchase Decisions During Covid-19 Pandemic Through Consumer Satisfaction as A Mediating Variable
}

\author{
Ari Apriani \\ Universitas Dian Nusantara \\ Email: ari.apriani@undira.ac.id \\ Indonesia \\ Cristina Catur Widayati* \\ Universitas Mercu Buana \\ Email: catur.widayati@mercubuana.ac.id \\ Indonesia \\ Rizky Vita Losi \\ Universitas Pembangunan Panca Budi \\ Email: rizkyvitalosi@dosen.pancabudi.ac.id \\ Indonesia
}

\section{ABSTRACT}

The COVID-19 pandemic has made sectors experienced a decline in many businesses engaged in transportation services, especially aviation. Since lockdown was implemented, the Government has tightened entry rules in Indonesian territory by including a COVID-19 free certificate using the rapid test/PCR. The population in this study were all Citilink Airlines consumers in West Jakarta and 280 respondents as samples. This study was different from previous research by using different variables and models in this study. The method used in this study was quantitative analysis with SEM analysis tools and Smart PLS 3.3 tools. The results in this study indicated that price perception, service convenience, and service quality had a positive and significant effect on consumer satisfaction. Brand equity had no positive and significant effect on consumer satisfaction. Price perception on purchasing decisions had a negative and significant effect. Meanwhile, service convenience, service quality, and brand equity on purchasing decisions hada positive and significant effects.

Keywords: Citilink, Covid-19, price perception, service convenience, service quality, brand equity, customer satisfaction and purchase decisions.

\section{PRELIMINARY}

Since the first case of Covid-19 was announced on Monday, March 2th, 2020, Indonesia has reported 1,155 cases of the coronavirus with 102 deaths and 59 recovered patients. The number of cases that continue to grow has forced some regions to implement local lockdown policies, in addition to physical distancing (Kompas.com, March 29th, 2020). The impact of the COVID-19 outbreak has resulted in all PT Angkasa Pura II (Persero) airports temporarily suspending passenger flights for the period of 24 April - 1 June 2020 to prevent the spread of COVID-19. After the end of Large-Scale Social Restrictions (LSSR) in all regions of Indonesia, then we are entering a new normal era where airports in Indonesian territory have begun to open and there is a relaxation of policies regarding travel documents, and commercial aircraft transportation has been reopened on condition that they carry a COVID-19 free certificate (Rapid test/PCR).

Due to the COVID-19 pandemic and the implementation of the lockdown system, airport closures for some time, and restrictions on the number of passenger capacities, several air transportation companies, especially Citilink, experienced a significant decline. Even though during the COVID-19 pandemic, every air transportation company must be able to maintain its existence by providing the best service for all passengers.

In this study, the authors conducted different research than previous studies, the researchers presented with different variables and models in this study. Based on the description above, the main issue is whether there is an effect of price perception, service convenience, service quality, and brand equity on ticket purchase decisions during the Covid-19 pandemic through consumer satisfaction as a mediating variable (Case Study on Citilink Airlines Consumers).

THEORETICAL REVIEW

\section{Consumer Behavior}

Setiadi (2019) defines that consumer behavior as an action that is directly involved in obtaining, consuming, and disposing of a product or service, including the decisionmaking processes that precede and follow these actions. According to Kotler and Keller (2016), consumer buying behavior is influenced by the following factors: (1) Cultural Factor: (a) Sub-culture; (b) Social class; (2) Social Factor; (3) Personal Factor; (4) Psychological Factors

\section{Purchase Decision}

According to Tjiptono (2014), the purchase decision is a process where consumers recognize the problem, seek 


\author{
E-ISSN: 2469-6501 \\ VOL: 7, ISSUE: 8 \\ August/202 1 \\ DOI: http://dx.doi.org/10.33642/ijbass.v7n8p5

information about a particular product or brand, and evaluate how well each alternative can solve the problem, which then leads to a purchase decision. According to Sunyoto (2012), purchasing decision indicators is: (a) Decisions about product types; (b) Decision about the shape of the product; (c) Decisions about brands; (d) Decision about the seller; (e) Decision on product quantity

\section{Customer Satisfaction}

According to Zeithaml and Bitner (2013), the definition of satisfaction is a response or consumer response regarding the fulfillment of needs. Satisfaction is an assessment of the characteristics or features of a product or service, or the product itself, which provides a level of consumer pleasure related to meeting consumer consumption needs. Customer satisfaction indicators according to Tjiptono (2014) are as follows: (a) Quality goods and services. Good quality products and excellent service; (b) Relationship marketing. Efforts to establish long-term relationships with customers; (c) Loyalty promotion program. Give some kind of appreciation to the customer; (d) Focus on the best customers. Focus on the 20 percent of customers who regularly consume 80 percent of sales; (e) Effective complaint handling system. Have an effective complaint handling system; (f) Unconditional guarantees. An explicit promise made to customers about the level of performance they can expect to receive; (g) Pay-for-performance programs. The customer satisfaction program cannot be implemented without the support of the organization's human resources.

\section{Brand Equity}

According to Aaker (2013), brand equity is a set of assets and brand trustworthiness associated with a particular brand, name, symbol, which can increase or decrease the value provided by a product for consumers. Aaker describes brand assets that contribute to the creation of brand equity into four dimensions, is brand awareness, perceived quality, brand association, and brand loyalty (Tjiptono, 2011).

\section{Service Quality}

Service quality can also be defined as all forms of service delivery provided optimally by the company to meet customer needs under customer expectations (Sahanggamu, et al., (2015). Service quality is defined as an act or act of a person or organization aiming to provide satisfaction to customers or employees (Kasmir, 2017). According to Zeithaml, the measure of service quality has ten dimensions (Hardiyansyah, 2011) but has been simplified into five dimensions, namely: Tangible (Intangible), Reliability (Reliability), Responsiveness (Responsiveness), Assurance (Assurance), and Empathy (Empathy).

\section{Service Convenience}

Service convenience is one of the company's strategies to meet the needs in the form of minimizing the time and effort of consumers to get benefits which ultimately results in satisfaction and consumer confidence to return to consuming the same product or service, to maintain the relationship between customers and companies that provide services. Sumarno, et al., 2016).

Tjiptono (2009) identified five dimensions of service convenience, namely: decision convenience (destination convenience), access convenience (accessibility convenience), transaction convenience (transaction convenience), benefit convenience (comfort benefits), post benefit convenience (comfort after experiencing benefits).

a) Decision convenience is the consumer's perception of the cost of time and effort to decide to purchase or use services. This decision includes whether to do it yourself or buy a service (make or buy decision).

b) Access convenience, namely the consumer's perception of the cost of time and effort to initiate service delivery. This includes actions that the customer must take to order or request services/services and in some cases, the customer must be present or present to receive the company's services/services.

c) Transaction convenience, namely the customer's perception of the cost of time and effort to enter into a transaction. This type of convenience focuses on the actions that the customer must take to get the right to use the service.

d) Benefit convenience, is the customer's perception of the cost of time and effort to experience the core benefits of the service.

e) Post benefit convenience (comfort after feeling the benefits), namely the customer's perception of the cost of time and effort when contacting the service provider again after the service benefit (benefit stage).

\section{Price Perception}

Lee, et al., (2011) suggests that price perception is a consumer's assessment and the associated emotional form regarding whether the price offered by the seller and the price compared to other parties is reasonable, acceptable, or justifiable. According to Kotler in Muharam and Soliha's research (2017) price perception can be measured through several indicators consisting of: (a) Price match with product quality; (b) Price match with benefits; (c) Competitive price.

\section{Conceptual Framework}

Referring to the analysis of the theory and concepts that have been stated above, that there are several problems of price perception, service convenience, service quality, and brand equity that cannot be separated from consumer satisfaction that affect purchasing decisions, then a theoretical framework is drawn up which dramatically describes the line of thought developed in this research. 


\title{
International Journal of Business and Applied Social Science (IJBASS)
}

\author{
E-ISSN: 2469-6501 \\ VOL: 7, ISSUE: 8 \\ August/2021 \\ DOI: http://dx.doi.org/10.33642/ijbass.v7n8p5 \\ (c) (7) \\ https://creativecommons.org/licenses/by/4.0/
}

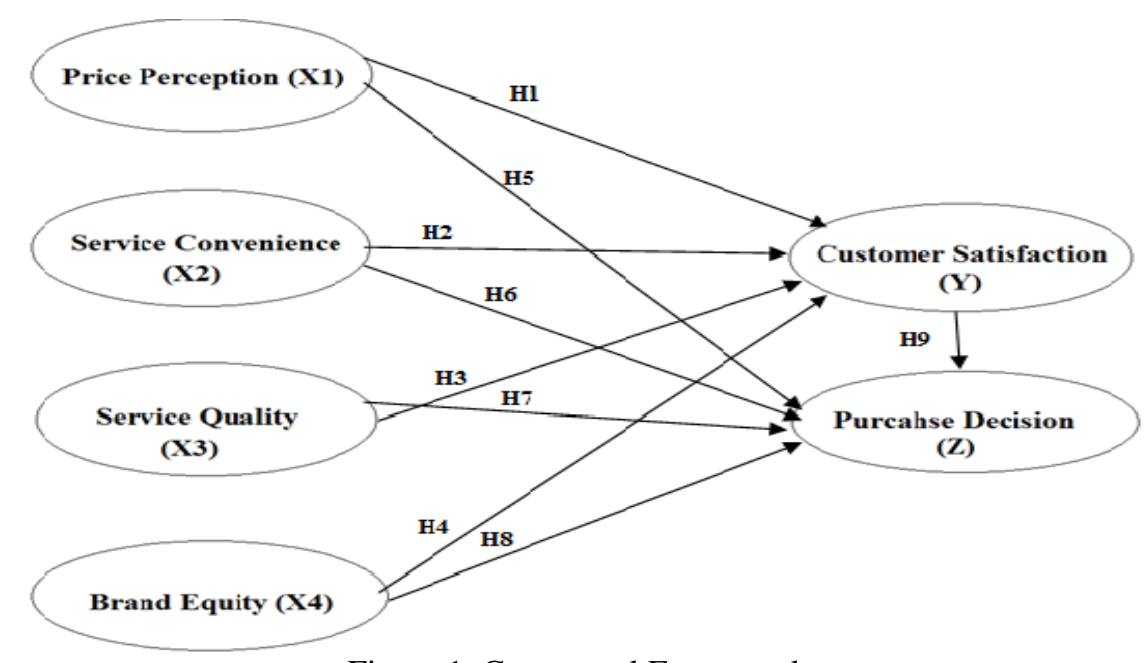

Figure 1. Conceptual Framework

Based on the description of the framework above, the following research hypotheses were developed:

H1: Perception of price affects consumer satisfaction

H2: Service convenience affects customer satisfaction

H3: Service quality affects customer satisfaction

H4: Brand equity affects consumer satisfaction

H5: Price perception affects purchasing decisions

H6: Service convenience affects purchasing decisions

H7: Service quality affects purchasing decisions

H8: Brand equity affects purchasing decisions

H9: Consumer satisfaction affects purchasing decisions

METHOD

This research was conducted by using a descriptive method and through a quantitative approach. Descriptive research aims to describe the characteristics of a particular group. Quantitative analysis was chosen because this study aimed to determine the relationship between these variables, the values expressed in numerical form, or more emphasis on data in the form of numbers that are processed mathematically with statistical formulas. The quantitative approach is a research method based on the philosophy of potivism, used to examine certain populations or samples, Sugiyono (2018) because this research is in the form of numbers and analysis uses statistics to measure and obtain research results through questionnaires. The population is the whole element with unexpected characteristics, while the sample is part of the population to be tested (Suliyanto, 2018). The population in this study is Citilink Airlines consumers in West Jakarta. According to Hair, et al., (2014), some guidelines for determining the sample size for SEM are given as follows: (1) If the parameter estimation uses the maximum likelihood estimation method, the recommended sample size is between 100 to 200, with a minimum sample of 50. (2) As much as 5 to 10 times the number of parameters in the model. (3) Equal to 5 to 10 times the number of manifest variables (indicators) of all latent variables. In this study there are 56 indicators so that referring to the third rule, the sample is $56 \times 5$, is 280 respondents.
Data was collected by using a questionnaire technique, where respondents answered questions that had been arranged in the form of choices and the question scale used a Likert scale (1-5). The data analysis method in this study was SEMPLS assisted by SmartPLS 3.3 software.

\section{RESULTS AND DISCUSSION}

\section{Evaluation of Measurement Model}

Validity testing for formative indicators shows a change in an indicator in the construct if other indicators in the same construct change or are removed from the model. The loading factor value in each construct of the recommended loading factor value is $>0.7$. The value of convergent validity is the value of the loading factor on the latent variable with its indicators. The desired value for Convergent Validity is $>0.7$ (Hussein, 2015). Based on the research data, all indicators were valid and showed that the loading factor value in each construct was $>0.7$. The lowest indicator value was the Y2 indicator with a value of 0.806 and the indicator as the highest value X1.3 was 0.976 , then the indicators in this study had all been declared valid or met the convergent validity test.

The second validity test is to see the Average Variance Extracted (AVE) value. According to Ghozali (2014), the Average Variance Extracted (AVE) value must be greater than 0.5 . The results of this study stated that all variables had met the requirements of the convergent validity test because the value of each variable was above 0.5 , namely price perception (X1) had a value of 0.947 , service convenience (X2) had a value of 0.863 , service quality (X3) had a value of 0.851 , brand equity (X4) had a value of 0.913 , consumer satisfaction (Y) had a value of 0.779 and purchase decisions (Z) had a value of 0.811 . Another measurement that is also used to test reliability is to use the AVE value. The aim is to measure the level of variance of a construct component that is compiled from its indicators by adjusting for the error rate.

After this, a discriminant validity test is carried out, discriminant validity is assessed based on the Fornell Larcker criterion and cross-loading. Discriminant validity can also be seen in the Fornell larcker criterion test by comparing the 


\author{
E-ISSN: 2469-6501 \\ VOL: 7, ISSUE: 8 \\ August/2021
}

DOI: http://dx.doi.org/10.33642/ijbass.v7n8p5 (c) (i)

https://creativecommons.org/licenses/by/4.0/

square root of the AVE for each construct with the correlation value between constructs in the model (Ghozali, 2014). A construct is declared valid if it has the square root of the highest AVE to the target construct compared to the square root of the AVE to other constructs.

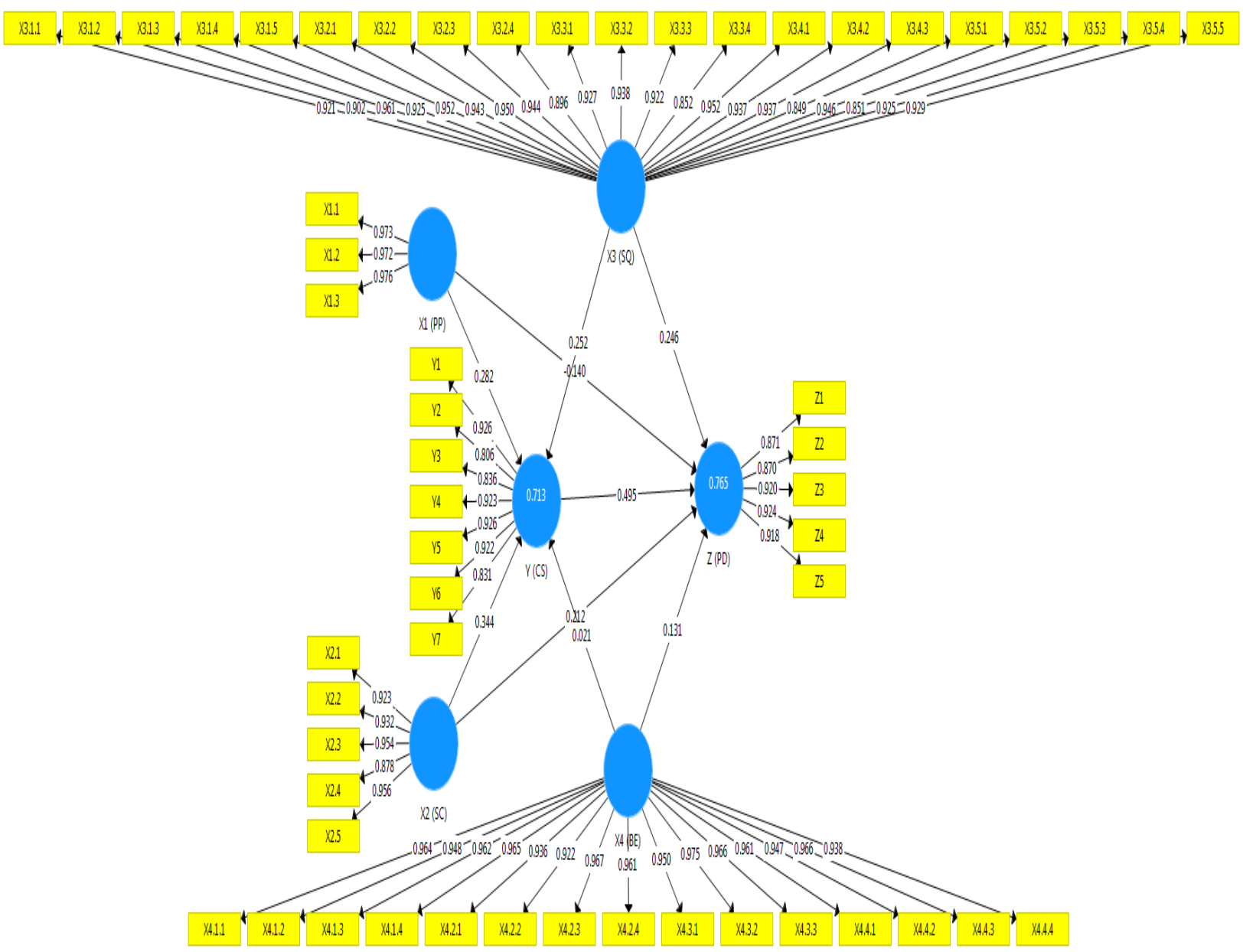

Figure 2. Measurement Model
Based on the results of the study, it was stated that the Fornell larcker criterion or the square root value of all variables showed that the square root value of the AVE was higher than the correlation value between other variables. 
VOL: 7, ISSUE: 8

August/2021

DOI: http://dx.doi.org/10.33642/ijbass.v7n8p5

(c) (i)

https://creativecommons.org/licenses/by/4.0/

Table 1. Hypothesis Test

\begin{tabular}{|c|c|c|c|c|c|}
\hline Hypothesis & Effect & $\begin{array}{c}\text { Path } \\
\text { Coefficients }\end{array}$ & $\begin{array}{c}\mathrm{t}- \\
\text { Statistic }\end{array}$ & P-Value & Result \\
\hline $\mathrm{H} 1$ & $\begin{array}{l}\text { Price perception affects } \\
\text { consumer satisfaction }\end{array}$ & 0.282 & 4.082 & 0.000 & Proven \\
\hline $\mathrm{H} 2$ & $\begin{array}{l}\text { Service convenience } \\
\text { affects consumer } \\
\text { satisfaction }\end{array}$ & 0.344 & 6.072 & 0.000 & Proven \\
\hline H3 & $\begin{array}{l}\text { Service quality affects } \\
\text { consumer satisfaction }\end{array}$ & 0.252 & 2.977 & 0.003 & Proven \\
\hline $\mathrm{H} 4$ & $\begin{array}{l}\text { Brand equity affects } \\
\text { consumer satisfaction }\end{array}$ & 0.021 & 0.413 & 0.680 & Rejected \\
\hline H5 & $\begin{array}{l}\text { Price perception affects } \\
\text { purchasing decisions }\end{array}$ & -0.140 & 2.315 & 0.021 & Proven \\
\hline H6 & $\begin{array}{l}\text { Service convenience } \\
\text { affects purchasing } \\
\text { decisions }\end{array}$ & 0.212 & 3.478 & 0.001 & Proven \\
\hline $\mathrm{H} 7$ & $\begin{array}{l}\text { Service quality affects } \\
\text { purchasing decisions }\end{array}$ & 0.246 & 2.974 & 0.003 & Proven \\
\hline $\mathrm{H} 8$ & $\begin{array}{l}\text { Brand equity affects } \\
\text { purchasing decisions }\end{array}$ & 0.131 & 2.306 & 0.022 & Proven \\
\hline H9 & $\begin{array}{l}\text { Consumer satisfaction } \\
\text { affects purchasing } \\
\text { decisions }\end{array}$ & 0.495 & 8.198 & 0.000 & Proven \\
\hline
\end{tabular}

\section{Results and Discussion}

Hypothesis testing using the PLS-SEM method is broadly divided into two stages, namely evaluation of measurement model and evaluation of the structural model. Evaluation of the measurement model can be said to be an analysis of validity and reliability, while evaluation of the structural model is used to test hypotheses.

a. Price Perception Has a Positive and Significant Effect on Consumer Satisfaction

The results of this study indicated that price perception had a positive and significant effect on consumer satisfaction with a path coefficient test of 0.282 and t-statistic (4.082) > from t-table (1.960). This was in line with previous research by Harjati \& Venice (2015) which stated that price perception had a positive and significant effect on customer satisfaction. Paramananda \& Sukaatmadja's research (2018) stated that price perception had a positive and significant impact on customer satisfaction. Meanwhile, in this study, competitive prices are indicators that have a strong relationship in the price perception variable. Cheaper and affordable prices are the target of consumers because during the pandemic consumers have to pay more for travel costs to arrange a COVID-19 free certificate with Rapid Test/PCR so that consumers are more dominant in looking for relatively affordable plane ticket prices.

b. Service Convenience Had a Positive and Significant Effect on Consumer Satisfaction

The results of this study indicate that service convenience had a positive and significant effect on consumer satisfaction with the path coefficient test of 0.344 and the t- statistic (6.072) > from t-table (1.960). This was in line with research by Anugrowati (2014) which stated that based on the results of research through simple regression analysis, there was a significant effect of service convenience on airline service user satisfaction. Sutanto's research (2020) stated that service convenience had a positive impact on customer satisfaction. It was proven that service convenience could encourage customer satisfaction. In this study, post-benefit convenience is an indicator that has a strong relationship in the service convenience variable. Consumers are satisfied with the services provided if they have felt the benefits they have felt.

\section{c. Service Quality Had a Positive and Significant Effect on Consumer Satisfaction}

The results of this study indicated that service quality had a positive and significant effect on customer satisfaction with a path coefficient test of 0.252 and t-statistic (2.977) > from t-table (1.960). This was in line with research by Shen \& Yahya (2021) which stated that service quality had a significant positive effect on passenger satisfaction. In addition, the findings of this study also confirm the mediating role of customer satisfaction between service quality separately which implies that customer satisfaction is an important factor for LCC to survive in the highly competitive aviation market. Meanwhile, this study contradicted the research of Tresiya, et al., (2018) which stated that service quality had no effect on customer satisfaction. In this study, the discipline of officers/apparatus is an indicator that has a strong relationship in the service quality variable. Consumers are satisfied with the services of disciplined officers and always try to provide timely service. 


\title{
International Journal of Business and Applied Social Science (IJBASS)
}

\author{
E-ISSN: 2469-6501 \\ VOL: 7, ISSUE: 8 \\ August/2021 \\ DOI: http://dx.doi.org/10.33642/ijbass.v7n8p5 \\ (c) (7) \\ https://creativecommons.org/licenses/by/4.0/
}

\section{d. Brand Equity Had a Positive and Insignificant Effect on Consumer Satisfaction}

The results of this study indicated that brand equity had a positive and insignificant effect on consumer satisfaction with a path coefficient test of 0.021 and t-statistic $(0.413)<$ from t-table (1.960). This was not in line with the research of Wicaksana, et al., (2018) which stated that brand equity had a significant effect on customer satisfaction. Mubarok's research (2018) also stated that brand equity had a positive and significant effect on customer satisfaction. In this study, believing that a good company is part of a brand is an indicator that has a strong relationship in the brand equity variable. Consumers are satisfied by assessing the airline as good or not, and it also has an influence but does not significantly contribute to customer satisfaction.

e. Price Perception Had a Negative and Significant Effect on Purchase Decisions

The results of this study indicated that price perception had a negative and significant effect on purchasing decisions with a path coefficient test of -0.140 and t-statistic (2.315) > from t-table (1.960). This was not in line with Manihuruk's (2020) research which stated that price perceptions had a positive and insignificant effect on purchasing decisions. Meanwhile, in the study of Samosir \& Prayoga (2015), it is stated that price perception has a positive and significant effect on purchasing decisions. In this study, the suitability of price with benefits is an indicator that has a weak relationship in the price perception variable, consumers will decide to buy if they feel that the price offered is reasonable in accordance with the facilities provided. The decision about the seller is an indicator that has a strong relationship in the purchase decision variable, consumers will certainly choose which seller provides a good price offer and it has a significant effect on purchasing decisions.

\section{f. Service Convenience Had a Positive and} Significant Effect on Purchase Decisions

The results of this study indicated that service convenience had a positive and significant effect on purchasing decisions with a path coefficient test of 0.212 and tstatistic (3.478) > from t-table (1.960). This was in line with the research of Sumarno et.al (2016) which stated that service convenience had been proven to have a positive and significant effect on purchasing decisions. Meanwhile, Susanti's research (2020) stated that service convenience had a significant positive effect on purchasing decisions. It was proven that service convenience could encourage purchasing decisions. Consumers will decide to buy if consumers have felt comfortable with the services provided.

\section{g. Service Quality Had a Positive and Significant Effect on Purchase Decisions}

The results of this study indicated that service quality had a positive and significant effect on purchasing decisions with a path coefficient test of 0.246 and t-statistic (2.974) > from t-table (1.960). This was in line with the research of
Firdausy \& Idawati (2017) which stated that service quality had a positive and significant effect on purchasing decisions. Meanwhile, Manihuruk's research (2020) stated that service quality had a positive and significant effect on purchasing decisions. It was proven that service quality can encourage purchasing decisions. Consumers will decide to buy if they feel that the service is from officers who are disciplined and always tries to provide timely service.

\section{h. Brand Equity Had a Positive and Significant Effect on Purchase Decisions}

The results of this study indicated that brand equity had a positive and significant effect on purchasing decisions with a path coefficient test of 0.131 and t-statistic (2.306) > from t-table (1.960). This was in line with research by Dewi, et al. (2013) which stated that brand equity and promotion variables had a joint effect on purchasing decisions. While Pradipta's research, et al., (2016) stated that simultaneously brand equity had a significant influence on purchasing decisions, partially the variables of brand equity showed significant results on purchasing decisions. It was proven that brand equity can encourage purchasing decisions. Consumers will decide to buy if the airline is a brand that is considered good.

i. Consumer Satisfaction had a Positive and Significant Effect on Purchase Decisions

The results of this study indicated that brand equity had a positive and significant effect on purchasing decisions with a path coefficient test of 0.495 and t-statistic (8.198) > from t-table (1.960). This was in line with the research of Maulidita \& Masreviastuti (2018) which stated that the purchasing decision variable could be explained by the customer satisfaction variable, while the rest by other variables which were not included in this study. It was proven that customer satisfaction could drive purchasing decisions. Meanwhile, Muiszudin's research (2016) said that consumer satisfaction had a positive effect on purchasing decisions. It was also proven that customer satisfaction could drive purchasing decisions. Consumers will decide to buy because they have judged that the goods and services received are of high quality.

\section{CLOSING}

\section{Conclusions}

Based on the results of the analysis and discussion, the following conclusions can be drawn:

1. Price perception has a positive and significant influence on consumer satisfaction, which if a positive price perception is formed, will trigger an increase in Citilink Airlines customer satisfaction.

2. Service convenience has a positive and significant influence on customer satisfaction, so it can be concluded that good service convenience will trigger an increase in Citilink Airlines' customer satisfaction.

3. Service quality has a positive and significant influence on customer satisfaction, this proves that the 


\author{
E-ISSN: 2469-6501 \\ VOL: 7, ISSUE: 8 \\ August/2021 \\ DOI: http://dx.doi.org/10.33642/ijbass.v7n8p5 \\ (c) (i) \\ https://creativecommons.org/licenses/by/4.0/
}

service quality provided to consumers properly will trigger an increase in Citilink Airlines' customer satisfaction.

4. Brand equity has a positive and insignificant effect on consumer satisfaction, this proves that Citilink's brand equity can trigger an increase in consumer satisfaction but not significantly.

5. Price perception has a negative and significant influence on purchasing decisions, where if there is a perception of prices elsewhere offering competitive prices, consumers will switch to other airlines and this triggers a very significant decision to purchase Citilink Airlines tickets.

6. Service convenience has a positive and significant influence on purchasing decisions, so it can be concluded that good service convenience will trigger an increase in Citilink Airline's ticket purchasing decisions.

7. Service quality has a positive and significant influence on purchasing decisions, this proves that the service quality provided to consumers properly will trigger an increase in Citilink Airline's ticket purchasing decisions.

8. Brand equity has a positive and significant influence on purchasing decisions, this proves that Citilink's brand equity can trigger an increase in Citilink Airline's ticket purchasing decisions.

9. Consumer satisfaction has a positive and significant influence on purchasing decisions, this proves that satisfied consumers will trigger an increase in Citilink Airline's ticket purchasing decisions.

\section{Suggestion}

1. Further studies are needed using other variables or adding other indicators and can also use different concepts. As for other factors that influence purchasing decisions in addition to the variables raised in this study, among others, such as price, facilities, brand trust, etc.

2. For further researchers can conduct research development this research by using different research objects and adding the number of respondents in the objects of research.

\title{
REFERENCES
}

Aaker, David A. (2013). Manajemen Pemasaran Strategi. Edisi Kedelapan. Jakarta: Salemba Empat.

Anugrowati, M. (2014). Pengaruh Service Convenience Terhadap Kepuasaan Pengguna Jasa Maskapai Penerbangan Citilink (Doctoral dissertation, Universitas Pendidikan Indonesia).

Dewi, S. K., Prihartini, A. E., \& Listyorini, S. (2013). Pengaruh Ekuitas Merek Dan Promosi Terhadap Keputusan Penggunaan Jasa Maskapai Penerbangan Garuda Indonesia. Jurnal Ilmu Administrasi Bisnis, 2(3), 211-217.

Firdausy, C. M., \& Idawati, R. (2017). Effects of Service Quality, Price and Promotion on Customers' Purchase Decision of Traveloka Online Airline Tickets in Jakarta, Indonesia. International Journal of Management Science and Business Administration, 3(2), 42-49.

Hardiansyah. (2011). Kualitas Pelayanan Publik: Konsep, Dimensi, Indikator dan Implementasinya. Yogyakarta: Gava Media.

Harjati, L., \& Venesia, Y. (2017). Pengaruh kualitas layanan dan persepsi harga terhadap kepuasan pelanggan pada maskapai penerbangan Tiger Air Mandala. E-Journal Widya Ekonomika, 1(1), 64-74. Kotler, Philip and Keller, Kevin, L. (2016). Marketing Management, 15th Edition. Pearson Education, Inc.

Lee, Simon., Abdou Illia \& Lawson-Body, Assion. (2011). Perceived Price of Dynamic Pricing, Journal of Industrial Management + Data system.

Maulidita, A. R., \& Masreviastuti, M. (2018). Pengaruh Kualitas Pelayanan Dan Kepuasan Pelanggan Terhadap Keputusan Pembelian Tiket Kereta Api (Studi Pada Mahasiswa Jurusan Administrasi Niaga Politeknik Negeri Malang Tahun Akademik 2017/2018). Jurnal Aplikasi Bisnis, 4(1), 153-156.

Mubarok, A. (2018). Pengaruh Kualitas Pelayanan, Brand Equity Dan Kualitas Produk Terhadap Kepuasan Pelanggan (Studi Kasus Pada PT. Immortal Cosmedika Indonesia Wilayah Tangerang Selatan). Jurnal Pemasaran Kompetitif, 1(3).

Muharam, Wifky dan Soliha, Euis. (2017). Kualitas Produk, Citra Merek, Persepsi Harga dan Keputusan Pembelian Konsumen Honda Mobilio. Proseding Seminar Nasional Multi Disiplin Ilmu \& Call For Papers Unisbank, 755-762.

Muiszudin, A., \& Sista, O. (2017). Pengaruh Kepuasan Konsumen Terhadap Keputusan Pembelian Tiket Pesawat Di PT. Arwana Internusa Tour Pontianak. Jurnal Manajemen Motivasi. https://doi. org/10.29406/jmm. v12i1, 432.

Paramananda, N., \& Sukaatmadja, I. P. G. (2018). The impact of price perception and brand image on customer satisfaction and repurchase intention. International Journal of Economics, Commerce and Management, 6(10), 212-224.

Pradipta, D., \& Hidayat, K. (2016). Pengaruh Brand Equity Terhadap Keputusan Pembelian (Survei pada Konsumen Pembeli dan Pengguna Kartu Perdana simPATI Telkomsel di Lingkungan Mahasiswa Jurusan Administrasi Bisnis Angkatan 2012 \& 2013 Fakultas Ilmu Administrasi Universitas Brawijaya Malang). Jurnal Administrasi Bisnis, 34(1), 138-147. 
Sahanggamu, S., Mananeke, L., \& Sepang, J. (2015). Analisis Kualitas Layanan, Servicescape Dan Kepercayaan Terhadap Kepuasan Nasabah pada PT. Bank Sinarmas Bitung. Jurnal EMBA: Jurnal Riset Ekonomi, Manajemen, Bisnis dan Akuntansi, 3(1).

Samosir, C. B. H. (2015). Arief Bowo Prayoga K.(2015). Pengaruh Persepsi Harga dan Promosi Terhadap Keputusan Pembelian Konsumen Produk Enervon-C. Jurnal Ilmiah Manajemen dan Bisnis, 1(3).

Setiadi, N. J. (2019). Perilaku Konsumen: Perspektif Kontemporer pada Motif, Tujuan, dan Keinginan Konsumen.Edisi Revisi. Cetakan ketujuh. Jakarta: Kencana.

Shen, C., \& Yahya, Y. (2021). The impact of service quality and price on passengers' loyalty towards low-cost airlines: The Southeast Asia's perspective. Journal of Air Transport Management, 91, 101966.

Silaban, P. H., \& Manihuruk, B. K. (2020). Pengaruh Persepsi Harga, Promosi Dan Kualitas Pelayanan Terhadap Keputusan Pembelian Tiket Pesawat Secara Online Pada Situs Tiket. Com (Studi Kasus Masyarakat Kota Medan). Repository Universitas HKBP Nommensen.

Sugiyono. (2018). Metode Penelitian Kuantitatif. Bandung. Alfabeta.

Sumarno, S., Soesanto, H., \& Sufian, S. (2016). Studi Mengenai Keputusan Pembelian Dengan Pendekatan Service Encounter, Service Convenience Dan Product Knowledge Yang Dimediasi Oleh Purchase Intention Pada Bengkel PT. Astra International-Daihatsu Sales Operation Semarang. Jurnal Sains Pemasaran Indonesia (Indonesian Journal of Marketing Science), 15(02), 93-106.

Sunyoto, Danang. (2012). Konsep Dasar Riset Pemasaran Dan Perilaku Konsumen. Yogyakarta: CAPS (Center For Publishing Service).

Susanti, Evi. (2020). Pengaruh E-WOM, Kualitas Informasi, Sales Promotion, Dan Service Convenience Terhadap Keputusan Pembelian Tiket Bioskop Online Melalui Tix.Id Di Kota Pontianak. Jurnal Manajemen Update, 9(1).

Sutanto, F., \& Keni, K. Pengaruh Service Quality, Service Convenience, dan Perceived Price and Fairness terhadap Loyalitas Nasabah Bank dengan Kepuasan Nasabah sebagai Variabel Mediasi. Jurnal Manajemen Bisnis dan Kewirausahaan, 5(2), 129-134.

Tjiptono, F. (2011). Strategi Pemasaran Edisi 3. Yogyakarta: Andi.

Tjiptono, F. (2014). Pemasaran Jasa, Prinsip, Penerapan dan Peneltian. Yogyakarta: Andi.

Tresiya, D., \& Djunaidi, H. S. (2018). Pengaruh Kualitas Pelayana Dan Kenyama-naan Terhadap Kepuasan Konsumen Pada Perusahaan Jasa Ojek Online Go-Jek Di Kota Kediri. Jim EK, 1.

Wicaksana, T. A., Suharyono, \& Hidayat, K. (2018). Pengaruh Ekuitas Merek terhadap Kepuasan dan Loyalitas Pelanggan (Survei pada Pengguna Sepeda Motor Merek Honda Beat di Sarana Kartika Motor Kabupaten Malang). Jurnal Administrasi Dan Bisnis, 63(1), 74-81.

Zeithaml dan Bitner, M. J. (2013). Service Marketing, Sixth Edition. America: Mc Graw Hill. 